\title{
In Vitro Susceptibility of Four Serotypes of Enterohaemorrhagic Escherichia coli to Antimicrobial Agents
}

\author{
Shigeharu Oie, ${ }^{a}$ Masatada KaWAKAmi, ${ }^{a}$ Akira KamiYa, ${ }^{*, a}$ and Masaaki Tomita ${ }^{b}$ \\ ${ }^{a}$ Department of Pharmacy, Yamaguchi University Hospital; 1-1-1 Minamikogushi, Ube 755-8505, Japan: and \\ ${ }^{b}$ Yamaguchi Prefectural Research Institute of Health; 2-5-67 Aoi, Yamaguchi 753-0821, Japan. \\ Received August 7, 2001; accepted February 1, 2002
}

\begin{abstract}
We evaluated the in vitro susceptibility of four serotypes of enterohaemorrhagic Escherichia coli $(E$. coli O26, $E$. coli $0111, E$. coli 0157 , and $E$. coli 0165$)$ with diverse DNA patterns to antimicrobial agents. The minimum inhibitory concentrations (MIC) determined in a total of 83 strains using Mueller-Hinton agar under aerobic and anaerobic conditions were $0.015-0.12 \mu \mathrm{g} / \mathrm{ml}$ for ciprofloxacin, $0.06-1 \mu \mathrm{g} / \mathrm{ml}$ for norfloxacin, 2$64 \mu \mathrm{g} / \mathrm{ml}$ for fosfomycin without glucose-6-phosphate (G-6-P), 0.25-32 $\mu \mathrm{g} / \mathrm{ml}$ for fosfomycin with G-6-P, 2$\geqq 256 \mu \mathrm{g} / \mathrm{ml}$ for kanamycin, $0.125-2 \mu \mathrm{g} / \mathrm{ml}$ for cefoperazone, and $0.06-1 \mu \mathrm{g} / \mathrm{ml}$ for ceftazidime. The MIC of ciprofloxacin, norfloxacin, cefoperazone, and ceftazidime were low in all strains examined.
\end{abstract}

Key words enterohaemorrhagic Escherichia coli; susceptibility; ciprofloxacin; norfloxacin; cefoperazone; fosfomycin

Escherichia coli (E. coli) serotype O157: H7 was first recognized as a human pathogen during a 1982 investigation of two outbreaks of diarrhea, and is estimated to cause more than 20000 cases of infection and as many as 250 deaths each year in the United States. ${ }^{1,2)}$ In Japan, the incidence of this infection is also high as was observed in a large outbreak stemming from a school lunch in Sakai City in 1996 in which 12680 people were infected with E. coli $\mathrm{O} 157: \mathrm{H} 7$, and 3 of them died. ${ }^{3)}$

There is continuing controversy as to whether antimicrobial therapy should be performed for E. coli $\mathrm{O} 157: \mathrm{H} 7$ infection. Some investigators have suggested that administration of antimicrobial agents for this infection promotes release of verotoxin from this serotype or tends to induce secondary infection, thus arguing against antimicrobial therapy. ${ }^{4,5}$ Others have reported no effects of administration of antimicrobial agents for $E$. coli $\mathrm{O} 157: \mathrm{H} 7$ infection on the development of hemolytic uremic syndrome (HUS) or the microorganism discharge period. ${ }^{6,7)}$ In contrast, some studies have shown a significant decrease in the incidence of HUS after administration of appropriate antimicrobial agents such as fluoroquinolones for E. coli $\mathrm{O} 157: \mathrm{H} 7$ infection, or a significant decrease in the mortality rate after administration of a fluoroquinolone to this infection in a mouse model. ${ }^{8-10)}$

In general, effective oral antimicrobial agents should be administered for bacterial enterocolitis. ${ }^{9)}$ Enterohaemorrhagic $E$. coli has many 0 serotypes $(1,2,4,5,6,18,25,26$, $38,39,45,50,55,82,84,91,103,111,113,114,115,117$, $118,121,128,145,146,153,163,165)$ in addition to 0157. However, there are no data on drug susceptibility of enterohaemorrhagic E. coli other than E. coli O157. ${ }^{11-13)}$ Therefore, we evaluated E. coli $\mathrm{O} 26$, O111, and $\mathrm{O} 165$ which could be acquired in addition to E. coli $\mathrm{O} 157$.

\section{MATERIALS AND METHODS}

Susceptibility Tests The minimum inhibitory concentrations (MIC) were determined for the 83 strains of enterohaemorrhagic $E$. coli after $18 \mathrm{~h}$ incubation at $35^{\circ} \mathrm{C}$ by dilution on Mueller-Hinton agar (Difco, U.S.A.) under both aerobic and anaerobic conditions. As a control, E. coli NIHJ JC2 was used. The following agents were tested: ciprofloxacin
(Bayer Yakuhin, Ltd.), norfloxacin (Kyorin Pharm.), fosfomycin Na (Meiji Seika Kaisha, Ltd.) with or without $25 \mu \mathrm{g} / \mathrm{ml}$ of glucose-6-phosphate (G-6-P; Oriental Yeast Co., Ltd.) added, ${ }^{14)}$ kanamycin sulfate (Meiji Seika Kaisha, Ltd.), cefoperazone $\mathrm{Na}$ (Pfizer Pharm, Inc.), and ceftazidime (Glaxo Japan Co.). These agents were provided in the form of a bulk powder. Anaerobic incubation was performed using a disposable $\mathrm{O}_{2}$ absorbing and $\mathrm{CO}_{2}$ generating agent (AnaeroPack ${ }^{\circledR}$; Mitsubishi Gas Chemical Co.). The inocula ( ca. $10^{4}$ colony forming units/spot) were plated using a multipoint incubator (Sakuma Co.). MIC were defined as the lowest concentration of agent inhibiting visible growth.

Productivity of Verotoxin The production of verotoxin (Shiga-like toxin) was determined by VTEC-RPLA SEIKEN (Denka Seiken Co., Ltd., Tokyo, Japan) based on the reversed passive latex agglutination method.

Pulsed Field Gel Electrophoresis The preparation of high molecular weight chromosomal DNA was performed according to Murray et al. ${ }^{15)}$ Digestion was carried out by placing a small slice of an agarose plug in $200 \mu \mathrm{l}$ of reaction buffer with 30 units of $X b a$ I. Pulsed field gel electrophoresis was performed with the Bio-Rad Gene Path system in a $1 \%$ agarose gel in $0.5 \times \mathrm{TBE}$ buffer at $14^{\circ} \mathrm{C}$ with a linear ramp time of 4 to $50 \mathrm{~s}$ over a period of $20 \mathrm{~h}$. Thereafter, the gels were stained with ethidium bromide and photographed.

\section{RESULTS}

Table 1 shows the 83 examined strains of enterohaemorrhagic E. coli (E. coli $\mathrm{O} 26$, E. coli $\mathrm{O} 111$, E. coli $\mathrm{O} 157$, and E. coli $\mathrm{O} 165)$ and their productivity of verotoxin. Of the 83 strains, 82 were isolated in hospitals in Yamaguchi Prefecture (population, about 1600000) in Japan between June, 1997 and December, 1999. One strain was isolated in an outbreak in a home for the aged (27 patients with infection), 13 strains from 13 families (43 patients with familial infection), and 68 strains from 68 patients with sporadic infection. The other strain was isolated in a large outbreak (12680 patients with infection) in Sakai, Osaka Prefecture, Japan in 1996., ${ }^{3,16)}$ All 83 strains were confirmed to differ in DNA pattern by pulsed field gel electrophoresis.

Table 2 shows the range of MIC and $\mathrm{MIC}_{90}$ of 6 antimicro- 
Table 1. Characteristics of Eighty-Three Enterohaemorrhagic Escherichia coli

\begin{tabular}{lccc}
\hline \hline \multirow{2}{*}{ Serotype } & \multicolumn{3}{c}{ No. of strains producing } \\
\cline { 2 - 4 } & Verotoxin I & Verotoxin II & Verotoxin I \& II \\
\hline O26: H11 & 11 & & 1 \\
O26: NM ${ }^{a}$ & 1 & & \\
O111:NM & 3 & 26 & 35 \\
O157:H7 & & 2 & 3 \\
O157:NM & & 1 & \\
O165:NM & & & \\
\hline
\end{tabular}

a) NM: non motility. bial agents for the 83 strains of enterohaemorrhagic E. coli determined using Mueller-Hinton agar under aerobic and anaerobic conditions. The MIC of ciprofloxacin, norfloxacin, cefoperazone, and ceftazidime were $\leqq 2 \mu \mathrm{g} / \mathrm{ml}$ in all 83 strains under both conditions. The MIC of fosfomycin were lower with than without added G-6-P, and lower under anaerobic conditions than under aerobic conditions, being $\leqq 64$ $\mu \mathrm{g} / \mathrm{ml}$ in all 83 strains under both conditions. Kanamycin showed lower MIC under aerobic conditions than under anaerobic conditions and an especially high MIC ( $\geqq 256$ $\mu \mathrm{g} / \mathrm{ml})$ in 1 of the 83 strains.

\section{DISCUSSION}

There have been many reports of the drug susceptibility of

Table 2. Susceptibilty of Eighty-Three Enterohaemorrhagic E. coli Strains of Four Serotypes to Antimicrobial Agents

\begin{tabular}{|c|c|c|c|c|c|}
\hline \multirow{2}{*}{ Agent } & \multirow{2}{*}{$\begin{array}{c}\text { Serotype } \\
\text { (no. of strains) }\end{array}$} & \multicolumn{2}{|c|}{$\operatorname{MIC}(\mu \mathrm{g} / \mathrm{ml})$ under an aerobic condition } & \multicolumn{2}{|c|}{$\operatorname{MIC}(\mu \mathrm{g} / \mathrm{ml})$ under an anaerobic condition } \\
\hline & & Range & $\mathrm{MIC}_{90}$ & Range & $\mathrm{MIC}_{90}$ \\
\hline \multirow[t]{5}{*}{ Ciprofloxacin } & $\mathrm{O} 26(13)$ & $0.015-0.06$ & 0.06 & $0.06-0.12$ & 0.12 \\
\hline & O111(3) & 0.03 & 0.03 & $0.06-0.12$ & 0.12 \\
\hline & O157 (66) & $0.015-0.06$ & 0.06 & $0.06-0.12$ & 0.12 \\
\hline & $\mathrm{O} 165(1)$ & 0.06 & - & 0.12 & - \\
\hline & Total (83) & $0.015-0.06$ & 0.06 & $0.06-0.12$ & 0.12 \\
\hline \multirow[t]{5}{*}{ Norfloxacin } & O26 (13) & $0.06-0.12$ & 0.12 & $0.25-1$ & 0.5 \\
\hline & O111 (3) & 0.12 & 0.12 & 0.5 & 0.5 \\
\hline & O157 (66) & $0.06-0.5$ & 0.25 & $0.5-1$ & 1 \\
\hline & $\mathrm{O} 165(1)$ & 0.06 & - & 1 & - \\
\hline & Total (83) & $0.06-0.5$ & 0.25 & $0.25-1$ & 1 \\
\hline \multirow{5}{*}{ Fosfomycin } & O26 (13) & $16-32$ & 32 & $4-16$ & 16 \\
\hline & O111(3) & $32-64$ & 64 & $4-8$ & 8 \\
\hline & O157 (66) & $8-32$ & 32 & $2-16$ & 8 \\
\hline & O165 (1) & 32 & - & 8 & - \\
\hline & Total (83) & $8-64$ & 32 & $2-16$ & 16 \\
\hline \multirow{5}{*}{$\begin{array}{l}\text { Fosfomycin } \\
+ \\
\text { G-6-P }(25 \mu \mathrm{g} / \mathrm{ml})\end{array}$} & O26 (13) & $0.25-32$ & 32 & $0.25-8$ & 8 \\
\hline & O111(3) & 0.5 & 0.5 & $0.25-0.5$ & 0.5 \\
\hline & O157 (66) & $0.25-32$ & 2 & $0.25-4$ & 1 \\
\hline & O165 (1) & 4 & - & 1 & - \\
\hline & Total (83) & $0.25-32$ & 2 & $0.25-8$ & 1 \\
\hline \multirow[t]{5}{*}{ Kanamycin } & $\mathrm{O} 26(13)$ & $4-\geqq 256$ & 8 & $16-\geqq 256$ & 32 \\
\hline & O111(3) & 4 & 4 & $16-32$ & 32 \\
\hline & O157 (66) & $2-4$ & 4 & $16-64$ & 64 \\
\hline & O165 (1) & 2 & - & 16 & - \\
\hline & Total (83) & $2-\geqq 256$ & 8 & $16-\geqq 256$ & 64 \\
\hline \multirow[t]{5}{*}{ Cefoperazone } & O26 (13) & $0.125-1$ & 1 & $0.125-2$ & 2 \\
\hline & O111(3) & $0.125-0.25$ & 0.25 & $0.125-0.25$ & 0.25 \\
\hline & O157 (66) & $0.125-1$ & 0.25 & $0.125-2$ & 0.5 \\
\hline & O165 (1) & 0.5 & - & 0.5 & - \\
\hline & Total (83) & $0.125-1$ & 0.5 & $0.125-2$ & 1 \\
\hline \multirow[t]{5}{*}{ Ceftazidime } & O26 (13) & $0.125-0.25$ & 0.25 & $0.125-0.25$ & 0.25 \\
\hline & O111(3) & $0.06-0.15$ & 0.25 & $0.06-0.25$ & 0.25 \\
\hline & O157 (66) & $0.06-0.25$ & 0.25 & $0.125-1$ & 0.5 \\
\hline & O165 (1) & 0.5 & - & 1 & - \\
\hline & Total (83) & $0.06-0.5$ & 0.25 & $0.06-1$ & 0.25 \\
\hline
\end{tabular}


E. coli $\mathrm{O} 157$ among enterohaemorrhagic E. coli. Swerdlow et al. reported resistance of 1 strain of $E$. coli $\mathrm{O} 157: \mathrm{H} 7$ to streptomycin and tetracycline ${ }^{17)}$ while Meng et al. reported resistance of six of 118 strains (5.1\%) of E. coli $\mathrm{O} 157$ to one or both of these agents. ${ }^{18)}$ Stock and Wiedemann evaluated 139 E. coli strains including 18 strains of enterohaemorrhagic $E$. coli (serotype not described) and observed resistance of 9 strains $(6.5 \%)$ to kanamycin and resistance of 37 strains $(26.6 \%)$ to tetracycline, but high sensitivity of all strains to fluoroquinolone and cefoperazone. ${ }^{11)}$ Tsuboi et al. reported that growth of all of $43 \mathrm{E}$. coli $\mathrm{O} 157$ stains was inhibited at a concentration of $\leqq 0.13 \mu \mathrm{g} / \mathrm{ml}$ by several agents including ciprofloxacin and norfloxacin. ${ }^{12)}$ We previously reported that the minimum bactericidal concentrations (MBC) in 6 strains of E. coli $\mathrm{O} 157$ are high for fosfomycin, ampicillin, and tetracycline but low for ciprofloxacin, polymyxin $\mathrm{B}$, cefoperazone, and kanamycin. ${ }^{13)}$ However, in these studies, drug susceptibility of other enterohaemorrhagic $E$. coli than E. coli $\mathrm{O} 157$ was not examined. Therefore, we determined MIC of 4 antimicrobial agents widely used for intestinal infection and 2 bile excreting type cephem antibiotics among the 83 strains of four serotypes of enterohaemorrhagic $E$. coli under aerobic and anaerobic conditions.

Kanamycin showed a high MIC in 1 strain. The MIC of ciprofloxacin, norfloxacin, and fosfomycin with or without added G-6-P for all serotypes of enterohaemorrhagic E. coli examined, however, were less than the intestinal concentrations reached following their oral administration at routine doses. The MIC of cefoperazone and ceftazidime were also less than the intestinal concentrations reached following their parenteral administration at routine doses. ${ }^{19)}$ Of these five agents, ciprofloxacin, norfloxacin, cefoperazone, and ceftazidine had marked in vitro antimicrobial effects on four serotypes of enterohaemorrhagic E. coli.

\section{REFERENCES}

1) Riley L. W., Remis R. S., Helgerson S. D., McGee H. B., Wells J. G., Davis B. R., Hebert R. J., Olcott E. S., Johnson L. M., Hargrett N. T., Blake P. A., Cohen M. L., N. Engl. J. Med., 308, 681-685 (1983).

2) Boyce T. G., Swerdlow D. L., Griffin P. M., N. Engl. J. Med., 333, 364-368 (1995).

3) Fukushima H., Hashizume T., Morita Y., Tanaka J., Azuma K., Mizumoto Y., Kaneno M., Matsuura M., Konma K., Kitani T., Pediatr. Int., 41, 213-217 (1999).

4) Takahashi K., Narita K., Kato Y., Sugiyama T., Koide N., Yoshida T., Yokochi T., Antimicrob. Agents Chemother, 41, 2295-2296 (1997).

5) Ito T., Akino E., Hiramatsu K., Kansenshogaku Zasshi, 71, 130-135 (1997).

6) Robson W. L. M., Scott R. B., Fick G. H., J. Pediatr., 116, 589-592 (1990).

7) Proulx F., Turgeon J. P., Delage G., Lafleur L., Chicoine L., J. Pediatr., 121, 299-303 (1992).

8) Higami S., Nishimoto K., Kawamura T., Tsuruhara T., Isshiki G., Ookita A., Kansenshogaku Zasshi, 72, 266-272 (1997).

9) Shiomi M., Togawa M., Fujita K., Murata R., Pediatr. Int., 41, 228232 (1999).

10) Yoshimura K., Fujii J., Taniguchi H., Yoshida S. Immun. Med. Microbiol., 6, 101-108 (1999).

11) Stock I., Wiedemann B., Diagn. Microbiol. Infect. Dis., 33, 187-199 (1999).

12) Tsuboi I., Ida H., Yoshikawa E., Hiyoshi S., Yamaji E., Nakayama I., Nonomiya T., Shigenobu F., Shimizu M., Hara K., Sawa T., Mizuoka K., Antimicrob. Agents Chemother, 42, 431-432 (1998).

13) Oie S., Kamiya A., Tomita M., Matsusaki S., Katayama A., Iwasaki A., Biol. Pharm. Bull., 20, 584-585 (1997).

14) Barry A. L., Fuchs P. C., Antimicrob. Agents Chemother, 35, 12351238 (1991)

15) Murray B. E., Shingh K. V., Markowitz S. M., Lopardo H. A., Patterson J. E., Zervos M. J., Rubeglio E., Eliopoulos G. M., Rice L. B., Goldstein F. W., Jenkins S. G., Caputo G. M., Nasnas R., Moore L. S., Wong E. S., Weinstock G., J. Infect. Dis., 163, 780-785 (1991).

16) Yukioka H., Kurita S., Eur. J. Emerg. Med., 4, 165 (1997).

17) Swerdlow D. L., Woodruff B. A., Brady R. C., Griffin P. M., Tippen S., Donnell H. D., Ann. Intern. Med., 117, 812-819 (1992).

18) Meng J., Zhao S., Doyle M. P., Joseph S. W., Food Protect., 61, $1511-1514$ (1998).

19) Mbre J. J., Bennett D. R., Cranston J. W., Dickinson B.D., Glade M. J., McCann M. A., "Drug Evalutions Annual 1993," American Medical Association, Chicago, 1993, pp. 1362-1365. 